\title{
The Molecular and Structural Basis of HBV-resistance to Nucleos(t)ide Analogs
}

\author{
Nidhi Gupta ${ }^{1}$, Milky Goyal ${ }^{2}$, Catherine H. Wu ${ }^{1}$ and George Y. Wu*1 \\ ${ }^{1}$ Department of Medicine, Division of Gastroenterology-Hepatology, University of Connecticut Heath Center, Farmington, USA; \\ ${ }^{2}$ Department of Microbiology, College of Basic Sciences and Humanities, Punjab Agriculture University, Ludhiana, Punjab, India
}

\begin{abstract}
Infection with hepatitis B virus (HBV) is a worldwide health problem. Chronic hepatitis B can lead to fibrosis, liver cirrhosis, and hepatocellular carcinoma (HCC). Management of the latter two conditions often requires liver transplantation. Treatment with conventional interferon or pegylated interferon alpha can clear the virus, but the rates are very low. The likelihood, however, of viral resistance to interferon is minimal. The main problems with this therapy are the frequency and severity of side effects. In contrast, nucleos(t)ide analogs (NAs) have significantly lower side effects, but require long term treatment as sustained virological response rates are extremely low. However, long term treatment with NAs increases the risk for the development of anti-viral drug resistance. Only by understanding the molecular basis of resistance and using agents with multiple sites of action can drugs be designed to optimally prevent the occurrence of HBV antiviral resistance.

(c) 2014 The Second Affiliated Hospital of Chongqing Medical University. Published by XIA \& HE Publishing Ltd. All rights reserved.
\end{abstract}

\section{Introduction}

The hepatitis B virus (HBV) is estimated to affect more than 400 million individuals worldwide, ${ }^{1}$ and approximately two million people in United States. Chronic hepatitis B can lead to fibrosis, liver cirrhosis, and hepatocellular carcinoma (HCC). The geographical distribution of HBV infection varies widely (Fig. 1). High genomic variability of HBV has resulted in the evolution of eight distinct genotypes $(A-H)$, some of which are further divided into subtypes $\left(1,2\right.$ etc.). ${ }^{2}$

HBV was discovered in $1967,{ }^{3}$ but treatment was not available until the development of interferon, which was first

Keywords: HBV; HCC; Nucleos(t)ide analogs.

Abbreviations: $3 T C$, lamivudine; ADV, adefovir; cccDNA, covalently closed circular DNA; dTTP, 2'-deoxythymidine 5'-triphosphate; HCC, hepatocellular carcinoma; HBcAg, hepatitis B core antigen; HBeAg, hepatitis $\mathrm{B}$ e antigen; HBsAg, hepatitis B surface antigens; HBV, hepatitis B virus, HIV, human immunodeficiency virus; LdT, telbivudine; NA, nucleos(t)ide analog; ORF, open reading frame; pgRNA, pre-genomic RNA; PMPA, 9-((R)-2-((Bis (((isopropoxycarbonyl)oxy)methoxy)phosphinyl)methoxy)propyl)adenine fumarate; TDF, tenofovir disoproxil fumarate.

Received: 13 June 2014; Revised: 26 July 2014; Accepted: 27 July 2014

DOI: $10.14218 /$ JCTH.2014.00021.

* Correspondence to: George Y. Wu, Department of Medicine, Division of Gastroenterology-Hepatology, University of Connecticut Health Center, Farmington, CT 06030, USA. Tel: +1-800-535-6232, E-mail: wu@nso.uchc.edu used in $1976 .{ }^{4}$ This was the mainstay therapy until 1998 when the mechanistic similarity between human immunodeficiency virus (HIV) reverse transcriptase and HBV polymerase led to the study and approval of lamivudine, the first oral nucleos(t)ide analog (NA) approved for HBV treatment. Subsequently, several NAs were developed for HBV treatment, including adefovir in 2002 , entecavir in 2005, telbivudine in 2006, and tenofovir in 2008. ${ }^{5}$

Current treatment for HBV infection consists of two major classes: ${ }^{6}$ immuno-modulatory agents (interferon-based therapies) and oral NAs. Advantages of treatment with conventional interferon or pegylated (long-acting) interferon alpha include low risk of developing viral resistance and slightly increased clearance of HBV with time. However, severe side effects such as anxiety, depression, and anemia have limited its benefits. Although NAs have significantly lower side effects, long term treatment with NAs is generally required because the rate of sustained virological response is extremely low. ${ }^{5}$ Since the replication rate of HBV is high and a proof reading mechanism of its polymerase is absent, the mutation rate is very high, $1.4-3.6 \times 10^{-5}$ nucleotide substitutions per site per cycle. This results in a high risk for the development of drug resistance ${ }^{7}$ against NA therapy.

\section{Genome organization and genotypes}

HBV is one of smallest known animal viruses, $32-42 \mathrm{~nm}$ in diameter. The viral particle consists of an outer envelope and an inner nucleocapsid that enclose a viral DNA genome and other proteins (Fig. $2 \mathrm{a}$ ). The outer lipoprotein envelope has hepatitis B surface antigens ( $\mathrm{HBsAg}$ ) embedded in it. These antigens are found in blood either free or bound to viral particles. Free HBsAg is non-infectious, but is involved in induction of long-term immunity against HBV. ${ }^{9-11}$ The viral core consists of hepatitis B core antigen ( $\mathrm{HBCAg}$ ), hepatitis $B$ e antigen ( $\mathrm{HBeAg})$, a partially double stranded DNA molecule, and DNA polymerase. HBcAg is a non-secretory marker of infectious viral material found inside HBV-infected cells. $\mathrm{HBeAg}$ is a form of HBcAg secreted in blood, and is usually an accurate index of viral load. ${ }^{12-14}$ The polymerase, a DNAdependent DNA polymerase, is involved in reverse transcription for viral replication ${ }^{15-17}$ and is research target for the development of drugs against HBV. ${ }^{5,18-20}$

The compact organization and multiple overlapping open reading frames (ORFs) has required the HBV to utilize its genome efficiently (Fig. 2b). ${ }^{16,21}$ The viral genome consists of a $3.2 \mathrm{~kb}$ partially double-stranded DNA molecule with one end bound to DNA polymerase. There are four ORFs in the HBV genome that result in the transcription and translation of 
Gupta N. et al: The basis of HBV-resistance to nucleos(t)ide analogs

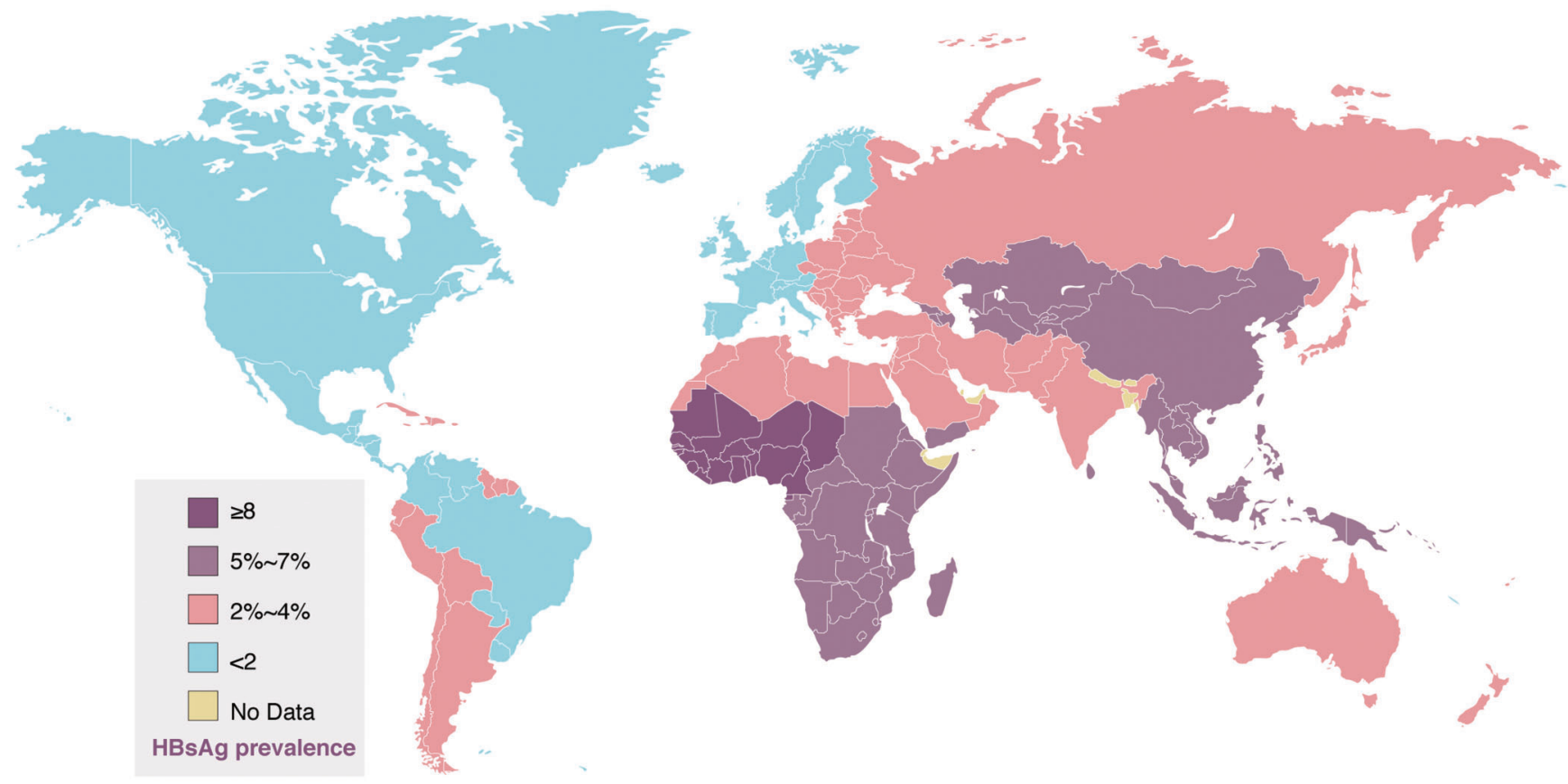

Fig. 1. Global prevalence of chronic hepatitis B virus (HBV) infection in adults. Source: Centers for Diseases Control and Prevention, CDC 2010

different types of proteins. $^{22}$ The core (C) gene encodes capsid proteins HBcAg and HBeAg; the P gene encode viral DNA polymerase; the $S$ gene has three in-frame start codons and codes for three envelope proteins that differ in lengths of the $\mathrm{N}$-termini (Fig. 2c). They are designated as large (L), major (M), and small (S) surface protein. $L$ and $M$ are surface proteins and are involved in hepatocyte receptor binding. The $\mathrm{S}$ surface protein is the protein detected in commercial assays as HBsAg. Finally, an $\mathrm{X}$ gene codes for a $16 \mathrm{kDa}$ protein $\mathrm{HBX}$ whose function is still not completely understood. It has been reported to modulate cellular signals, promoters, and cellcycle pathways, some of which have been implicated in the development of hepatocellular carcinoma. ${ }^{23-26}$

The eight genotypes of HBV $(\mathrm{A}-\mathrm{H})$ have a distinct geographical distribution (Table 1 ) and are classified based on $>8 \%$ divergence in complete genome sequence. ${ }^{27-29}$ The

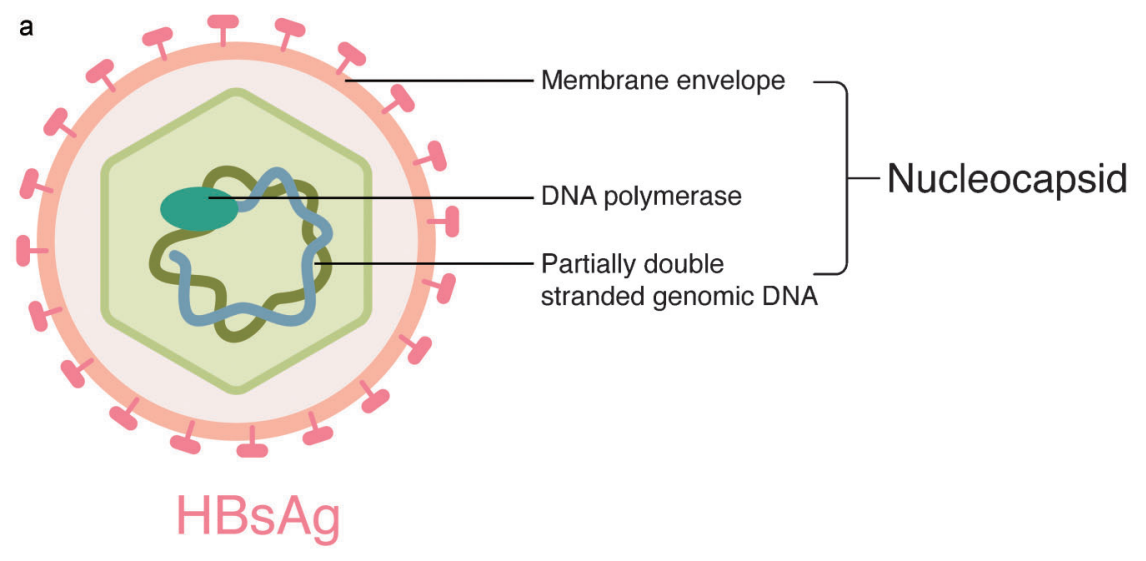

C

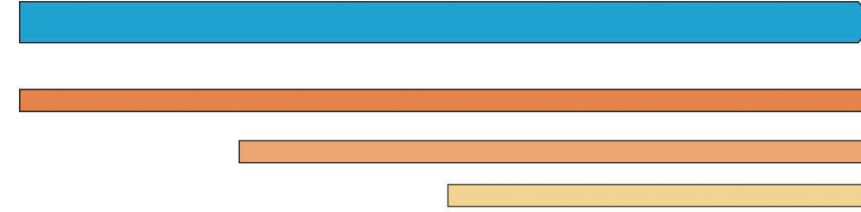

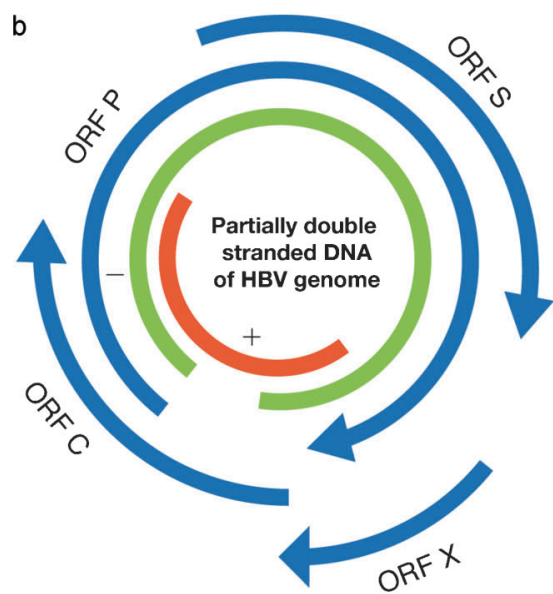

S gene

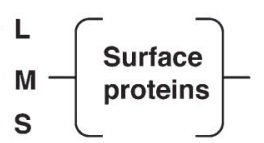

Fig. 2. Structural and genetic organization of HBV. a, structure of HBV; b, compact organization of the HBV genome showing multiple overlapping open reading frames; $c$, expression of three envelope proteins from three in-frame start codons from the S-gene of the HBV genome. 
prevalence of HBV genotypes varies highly, with $\mathrm{A}$ and $\mathrm{C}$ being most common (>30\%), and $E$ and $F$ being least common $(<0.6 \%)$ in the US. Four of these $(A, B, C$, and $F)$ are further divided into sub-genotypes based on genomic variability of $>4 \% .{ }^{29,30}$ Disease progression and response to anti-viral therapies differs in patients infected with different genotypes. ${ }^{31}$

\section{Life cycle and replication}

To understand current therapeutic approaches to HBV infection, knowledge of the HBV life cycle and replication is very important. HBV is a DNA virus, but it replicates like a retrovirus using reverse transcription. The initial steps of HBV entry into cells have been difficult to characterize. They are thought to involve cell membrane binding and endocytosis of viral particles. ${ }^{32}$ Several proteins have been proposed to assist in viral attachment to the cell surface and entry into the cell. For example, apolipoprotein $H_{1}^{33,34}$ poly-human serum albumin, ${ }^{35}$ fibronectin, ${ }^{36}$ interleukin- $6^{37,38}$ and carboxypeptidase D (gp 180) ${ }^{39,40}$ have all been proposed to play a role as HBV receptors. Recently, another $80 \mathrm{kDa}$ protein has been identified that binds HBV surface proteins. ${ }^{41}$ To date, the exact mechanism of HBV entry into cells is still not well elucidated.

Once viral particles enter the cell, the viral nucleocapsid is uncoated and delivered to the cell nucleus. ${ }^{42-44}$ In the nucleus, partially double-stranded HBV DNA is repaired to form covalently closed circular DNA (cccDNA), which serves as a template for transcription by cellular enzymes. ${ }^{45-47} \mathrm{HBV}$ DNA polymerase does not have repair mechanism activity. ${ }^{48}$ Also, unlike retroviruses, HBV DNA integration into host cell genome is not required for HBV replication. After recircularization, HBV DNA starts to express transcripts required for HBV protein synthesis and pre-genomic RNA (pgRNA) required for viral replication. Two types of transcripts are expressed: sub-genomic and genomic. Subgenomic, smaller transcripts, serve as templates for surface proteins and $\mathrm{HBx}$ expression. Genomic transcripts longer than one genome in length serve as templates for e, core, and polymerase expression. The HBV DNA polymerase selects genomic transcripts lacking the start 'ATG' codon at the 5' terminus as pgRNA for packaging into virions. ${ }^{49}$ Sub-genomic and genomic transcripts are then transported and translated in the cytoplasm. Binding of DNA polymerase protein to pgRNA results in encapsidation, ${ }^{50,51}$ and formation of RNA-

Table 1. Geographic Distribution of HBV Genotypes

\begin{tabular}{ll}
\hline $\begin{array}{l}\text { HBV } \\
\text { genotypes }\end{array}$ & Geographic distribution \\
\hline A & Northwest Europe, North America, Africa \\
B & Asia \\
C & Asia \\
D & Worldwide distribution \\
E & Africa \\
F & South America, Central America (Hispanic \\
& origin) \\
G & France, UK, Italy, Germany, USA \\
H & Central America (Amerindian populations) \\
\hline
\end{tabular}

Source: Ref [28] [145-153] containing nucleocapsids. After encapsidation, reverse transcription is then initiated upon interaction of the C-terminus of the DNA polymerase with core protein. Polymerase bound to pgRNA starts to reverse transcribe pgRNA into (-) DNA strand using a bulge in the stem loop of pgRNA. ${ }^{52-55}$ The RNase $\mathrm{H}$ activity of the polymerase degrades pgRNA after (-) DNA strand synthesis, ${ }^{56}$ leaving $13-20$ nt on the $5^{\prime}$-end that serve as primers for (+) DNA strand synthesis. ${ }^{16,57}$ Following the synthesis of viral DNA and nucleo-capsid packaging, HBV surface proteins aggregate in cellular Golgi bodies, forming vesicles around viral nucleocapsids that result in enveloped HBV particles. These particles are then secreted as mature virions by exocytosis. This occurs along with secretion of noninfectious particles, viral surface protein aggregates without enclosed nucleo-capsid. Although several steps of the HBV life cycle have been well characterized, ${ }^{17,46,58}$ many aspects remain unclear and need to be explored in order to fully understand the life cycle of HBV.

\section{In vitro screening assays for $\mathrm{HBV}$ resistance}

Currently, there are no practical animal models for testing antiviral drug efficacy. Drugs are tested pre-clinically with in vitro assays to determine both their efficiency and resistance profiles. ${ }^{59,60}$ In these assays, liver cells are infected with wild type or mutated HBV, and the effects of NAs are determined by measuring HBV replication or cytotoxicity. ${ }^{61}$ In vitro reverse transcription assays are performed to determine the effects of various mutations on resistance to NAs. Wild type or mutant HBV DNA polymerase is expressed from plasmids and tested for priming and elongation of viral DNA. ${ }^{62}$

\section{Clinical drug resistance rates}

Determining the rate of the development of resistance from clinical experience varies considerably depending on the agents. For lamivudine, the one year resistance rate is $30 \%$, and for telbivudine it is $15 \%$. When used individually, entecavir and adefovir have higher barriers of resistance, with rates less than $2 \%$ after two years. No resistance to tenofovir has yet been reported. After five years of treatment, the rates of resistance were about $70 \%$ for lamivudine, $28 \%$ for adefovir, less than $1 \%$ for entecavir, ${ }^{63-65}$ and $0 \%$ for tenofovir and interferon.

\section{Current treatment and mechanisms of HBV resistance}

\section{Interferon therapy}

Conventional interferon and pegylated (long-acting) interferon alpha are two drugs currently available and approved for HBV therapy. ${ }^{66-69}$ Interferon is an immunomodulator, ${ }^{70}$ acting indirectly to eliminate HBV-infected host cells by activating various host genes and innate immune response pathways. ${ }^{71-73}$ Its use has a number of advantages including a finite treatment course, ${ }^{74}$ lack of drug resistance, ${ }^{75}$ and a decreased risk of cirrhosis and HCC with long term use. ${ }^{76}$ However, the sustained virological response rate is generally poor (6\%) for PEG-interferon. However, there are substantial side effects, including fatigue, diarrhea, alopecia, flu-like symptoms, insomnia, and psychiatric complications, that often require additional medications to correct. 
Gupta N. et al: The basis of HBV-resistance to nucleos(t)ide analogs

\section{NAs}

The presence of extremely stable cccDNA HBV in infected hepatocytes is the major obstacle to permanent elimination of HBV. ${ }^{77,78}$ The cccDNA acts as template for viral RNA genome production. The DNA-dependent DNA polymerase of HBV catalyzes synthesis of RNA, RNase $H$, and protein priming activities along with replication of HBV genome. Recently, NAs have been developed to directly inhibit the function of HBV DNA polymerase by either competitive binding to the enzyme or by terminating viral replication prematurely, which inhibits viral genome production. NAs currently available for HBV treatment are shown in Fig. 3.

Lamivudine

Lamivudine [(-)- $\beta-L-2^{\prime}-3^{\prime}$ dideoxythiacytidine)] or 3TC was the first oral NA approved for the treatment of HBV (Fig. 3). 3TC is a cytidine analogue, and is phosphorylated intracellularly to 5'-triphosphate active metabolites. It inhibits DNA polymerase function by competing with a natural substrate (dCTP), resulting in DNA chain termination. Treatment with 3TC has been shown to not only suppress viral replication and HBV serum levels, but also to reverse fibrosis to varying degrees with long term use. ${ }^{79,80}$ Furthermore, it has been shown to decrease the risk of HCC. ${ }^{81,82}$ Lamivudine is a potent drug, but it unfortunately also has a high rate of drug resistance, which increases with duration of treatment. ${ }^{82-86}$

According to molecular model studies, residues F88, L180, and M204 play indirect, but crucial roles in the formation of a hydrophobic pocket and other non-covalent interactions in the DNA polymerase of HBV. ${ }^{87,88}$ These have been shown to be involved in the binding of NAs to the polymerase. Although slightly different structurally from natural cytosine, 3TC interacts with the HBV DNA polymerase active site perfectly, inducing a fitting movement of the M204 residue that results in significant inhibition of viral replication (Fig. 4). Long term use of 3TC for HBV treatment frequently leads to mutation of the M204 residue in the HBV DNA polymerase gene and gives rise to 3TC-resistant HBV. Three major mutations (M204I, M204V, and L180M) individually or in combinations in HBV DNA polymerase result in significant resistance against 3TC anti-viral characteristics (Table 2). Mutation of L180 to M180 orients the residue away from the hydrophobic pocket, resulting in reduced interaction of 3TC with HBV DNA polymerase. Mutations of M204 to I204 or V204 add a bulky group of branched residues to the hydrophobic pocket, creating steric hindrance that prevents accommodation of the 3TC ring (Fig. 4). This ultimately causes resistance by increasing the thermodynamic stability of binding of the natural substrate to HBV DNA polymerase compared to 3 TC. $^{89}$ Dual mutations (L180M + M204I or L180M + M204V) can further reduce the binding affinity of 3TC with HBV DNA polymerase by combining effects of reduced interaction (mutated L180) and steric effects (mutated M204) (Fig. 5).

\section{Adefovir dipivoxil (Adefovir, ADV)}

Adefovir (ADV), an acyclic adenosine analogue (Fig. 3), is phosphorylated to yield an active metabolite that inhibits HBV DNA polymerase activity by competing with the natural substrate (dATP). In doing so, it causes chain termination. Decreased potency of ADV is due to lower effective intracellular drug levels compared to other NAs. In addition, ADV has been associated with a dose-dependent nephrotoxicity and can lead to reversible renal impairment. ${ }^{90-92}$

Molecular modeling studies have shown that ADV interacts with HBV DNA polymerase in a way similar to dATP. ${ }^{89}$ Major<smiles>Nc1ccn(C2COC2CO)c(=O)n1</smiles>

Lamivudine (3TC)<smiles>Nc1ncnc2c1ncn2CCOCP(=O)(O)O</smiles>

Adefovir (ADV)<smiles>C=C1[C@@H](CO)[C@H](O)C[C@H]1n1cnc2c(=O)nc(N)[nH]c21</smiles>

Entecavir (ETV)<smiles>Cc1cn(C2CC(O)C(CO)O2)c(=O)[nH]c1=O</smiles>

Telbivudine (LdT)<smiles>C[C@H](Cn1cnc2c(N)ncnc21)OCP(=O)(O)O</smiles>

Tenofovir (TDF)

Fig. 3. Molecular structures of approved NAs 

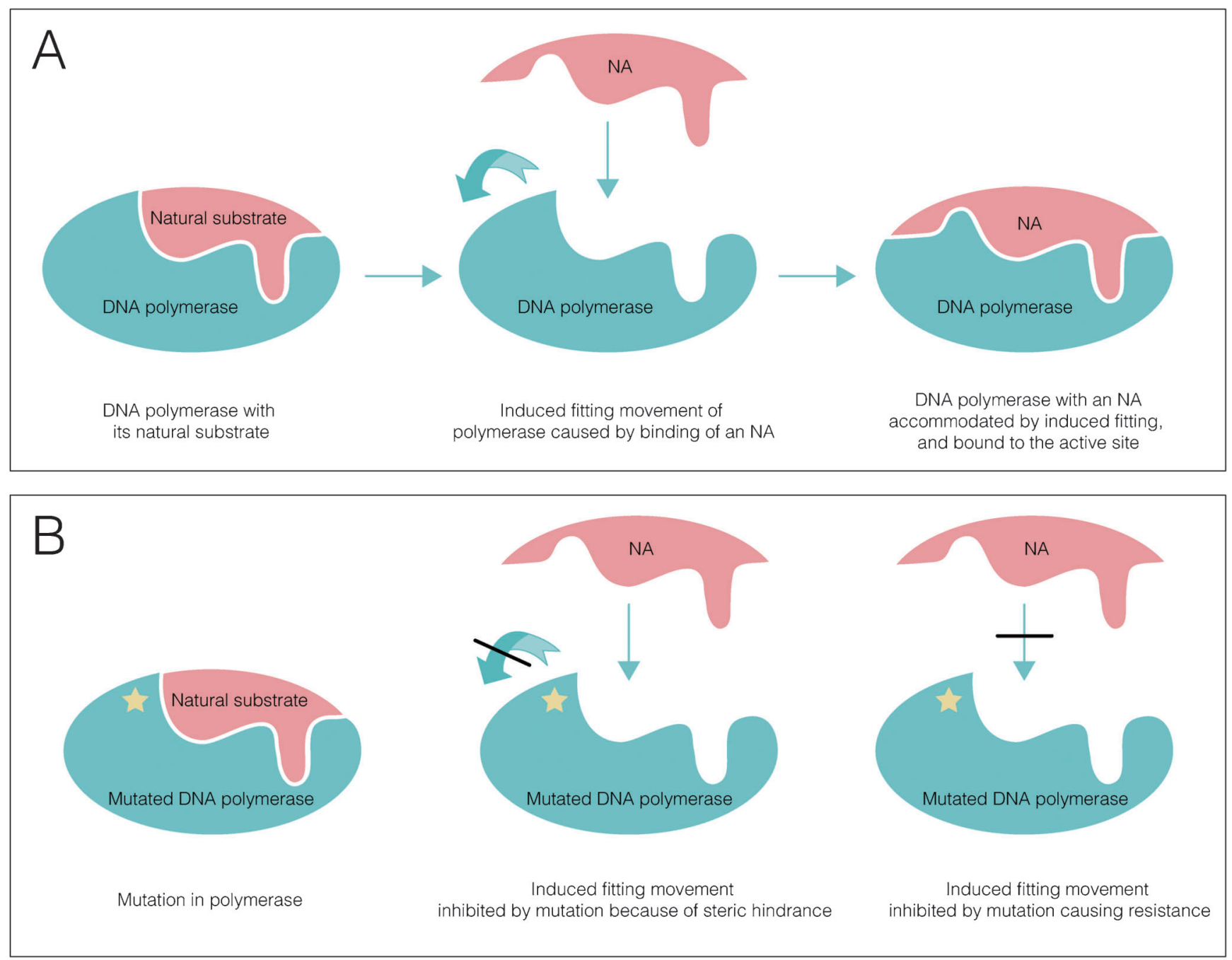

Fig. 4. Increased resistance to NAs caused by inhibition of induced fitting movement by a mutation near the active site. a, HBV DNA polymerase can bind to either natural substrate for HBV DNA synthesis or NAs by induced fitting movement at the active site; $b$, mutated HBV DNA polymerase can bind to natural substrate for HBV DNA synthesis. A mutation near the active site inhibits induced fitting movement of polymerase resulting in steric inhibition of binding of NA to polymerase.

mutations in the HBV DNA polymerase gene that cause ADV resistance are $\mathrm{A} 181 \mathrm{~V}, \mathrm{~A} 181 \mathrm{~T}, \mathrm{~N} 236 \mathrm{~T}$, and $\mathrm{I} 233 \mathrm{~V} .{ }^{93-95}$ Other mutations $(\mathrm{P} 237 \mathrm{H}, \mathrm{N} 238 \mathrm{~T} / \mathrm{D}, \mathrm{V} 84 \mathrm{M}, \mathrm{S} 85 \mathrm{~A}, \mathrm{~V} 214 \mathrm{~A}$, and Q215S) have also been reported to decrease sensitivity to ADV, although the exact mechanism remains unclear ${ }^{96}$ (Fig. 5). ADV binding to HBV DNA polymerase is not affected by mutations (M204I, M204V and L180M) that result in resistance to 3TC. As such, ADV is effective against lamivudine-resistant HBV polymerase. ${ }^{97,98}$

\section{Entecavir}

Entecavir (ETV) is a guanosine analogue (Fig. 3) that is phosphorylated intracellularly to an active metabolite. It inhibits multiple functions of HBV DNA polymerase, including polymerase priming, reverse transcription, and DNA synthesis. ${ }^{99-101}$ Unlike 3TC and ADV, ETV does not cause chain termination because it possess a $3^{\prime}$-hydroxyl group, ${ }^{102}$ so addition of nucleotides to the nascent chain continues. Molecular modeling studies have demonstrated that ETV forms most interactions with the active site of HBV DNA polymerase in a manner similar to the natural substrate (dGTP). It does not, however, require induced fit movements of any residue in the polymerase. ${ }^{89,100}$ This allows ETV to be more effective and less susceptible to the development of drug resistance. ${ }^{103-105}$ ETV inhibits HBV DNA elongation after addition of a few nucleotides by increasing steric hindrance and thereby preventing addition of more bases to the DNA. ${ }^{100}$ ETV is more potent than other NAs and has a higher rate of viral clearance. ${ }^{106-110}$ It also has a high barrier to the development of resistance because a single mutation is not sufficient to cause resistance. Rather, multiple mutations are required: I169T, T184G, S202I, or M250V in addition to L180M and $\mathrm{M} 204 \mathrm{~V} / \mathrm{I}$, the latter two result in resistance to $3 \mathrm{TC}^{111-113}$ (Fig. 5). Therefore, the risk of resistance is higher with HBV already resistant to 3 TC. ${ }^{111}$ 
Gupta N. et al: The basis of HBV-resistance to nucleos(t)ide analogs

Table 2. Anti-HBV Agents and Reported Resistance Mutations

\begin{tabular}{|c|c|c|}
\hline Analog & Type & HBV polymerase mutation \\
\hline Lamivudine & $\begin{array}{l}\text { Cytosine analog } \\
{\left[(-)-\beta-L-2^{\prime}-3^{\prime} \text { dideoxythiacytidine }\right]}\end{array}$ & $\begin{array}{l}\text { M204I/V, L180M, L180M-M204V, } \\
\text { L180M-M204I }\end{array}$ \\
\hline Adefovir & $\begin{array}{l}\text { Adenosine analog } \\
9-[2-[[\text { bis }[(\text { pivaloyloxy)methoxy]-phosphinyl]methoxy] } \\
\text { ethyl]adenine }\end{array}$ & $\mathrm{A} 181 \mathrm{~V} / \mathrm{T}, \mathrm{N} 236 \mathrm{~T}, \mathrm{I} 233 \mathrm{~V}$ \\
\hline Entecavir & $\begin{array}{l}\text { Guanosine analog } \\
\text { 2-amino-1,9-dihydro-9-[(1S,3R,4S)-4hydroxy-3-(hydroxymethyl)- } \\
\text { 2-methylenecyclopentyl]-6H-purin-6-one, monohydrate }\end{array}$ & I169T, T184G, S202I, M250V, M204I/V \\
\hline Telbivudine & $\begin{array}{l}\text { Thymidine analog } \\
1 \text {-(2-deoxy- } \beta \text {-L-ribofuranosyl)-5methyluracil }\end{array}$ & $\begin{array}{l}\text { M204I, L80I/V, L180M, A181 T/V, L229 } \\
\text { W/V }\end{array}$ \\
\hline Tenofovir & $\begin{array}{l}\text { Adenosine analog } \\
\text { 9-((R)-2-((Bis(((isopropoxycarbonyl)oxy)methoxy) phosphinyl)- } \\
\text { methoxy)propyl) adenine fumarate (PMPA) }\end{array}$ & $\mathrm{A} 181 \mathrm{~V}, \mathrm{~N} 236 \mathrm{~T}$ \\
\hline
\end{tabular}

Table 3. Reported Mutations and Associated Resistance Determined by in Vitro Assays

\begin{tabular}{llllll}
\hline Mutation & Lamivudine & Adefovir* & Entecavir & Telbivudine & Tenofovir* \\
\hline I169T & $>1000$ & 1.0 & $>1000$ & $>100$ & No data \\
A181T & $2-6$ & $1-5$ & No data & No data & $1-1.5$ \\
A181V & $2-6$ & $1-5$ & No data & No data & $2.9-10$ \\
T184G & $>1000$ & 2.0 & $>1000$ & $>1000$ & $0.6-6.9$ \\
S202I & $>1000$ & 2.0 & $>1000$ & $>1000$ & $0.6-6.9$ \\
M204I (YMDD) & $>1000$ & 0.7 & 30 & $>1000$ & $0.7-3.4$ \\
M204V (YMDD) & $>1000$ & 0.7 & No data & 1.2 & $0.7-3.4$ \\
V214A & $10-20$ & $7-10$ & No data & $7-10$ & $>10$ \\
Q214S & $10-20$ & $7-10$ & No data & $7-10$ & $>10$ \\
N236T & $3-8$ & $7-10$ & 0.67 & 2.4 & $2.9-10$ \\
M250V & $>1000$ & 1.0 & $>1000$ & 1.0 & $0.6-6.9$ \\
L80I + M204I & $>1000$ & $>10$ & No data & $>1000$ & 3.4 \\
L180M + M204V & $>1000$ & 0.2 & 30 & 133 & 3.4 \\
\hline
\end{tabular}

Source: Ref [59]

\section{Telbivudine}

Telbivudine (LdT) is an analog of thymidine (Fig. 3) with an Lconfiguration rather than the $\mathrm{D}$-configuration of natural nucleosides. It competes with natural dTTP (2'-deoxythymidine $5^{\prime}$-triphosphate) for the HBV DNA polymerase active site after phosphorylation intracellularly, leading to premature chain termination. ${ }^{114}$ Although LdT is more potent and less prone to drug resistance than $3 \mathrm{TC}^{115-118}$ the drug resistance rate is still relatively high. ${ }^{119,120}$ An M204I mutation greatly decreases LdT inhibition of HBV replication by altering the orientation and position of key methyl groups ${ }^{89}$ (Fig. 5). The L180M mutation results in the loss of another methyl group required for LdT affinity to the polymerase. Hence, dual mutations (M204I + L180M) make HBV DNA polymerase highly resistant to LdT. Other mutations L80I, A181T/V, and L229W/V have been linked to LdT resistance. ${ }^{5,121}$ Besides the high resistance rate, adverse reactions of LdT, such as myopathy, ${ }^{122}$ myalgia, ${ }^{123}$ creatine kinase elevations, ${ }^{124}$ and general weakness, have also been reported in various clinical trials. Mechanisms of these adverse reactions are not clearly understood, and further studies are required to further characterize them.

\section{Tenofovir}

Tenofovir disoproxil fumarate (TDF), 9-((R)-2-((Bis (((isopropoxycarbonyl)oxy)methoxy)phosphinyl)methoxy)propyI)adenine fumarate (PMPA) is an adenine analog (Fig. 3) that competes with dATP after intracellular phosphorylation, resulting in chain termination. TDF is more potent than ADV because of a high tolerance to increased doses of TDF compared to ADV. ${ }^{125-127}$ Despite long-term treatment, no evident resistance has been reported with TDF. ${ }^{128}$ However, some mutations, A181V and N236T, have been found to decrease susceptibility to TDF, ${ }^{129-131}$ although the exact mechanism by which this occurs is unknown. Mild renal toxicity ${ }^{132-134}$ and osteomalacia ${ }^{135,136}$ has been observed with long term TDF treatment. 
Gupta N. et al: The basis of HBV-resistance to nucleos(t)ide analogs

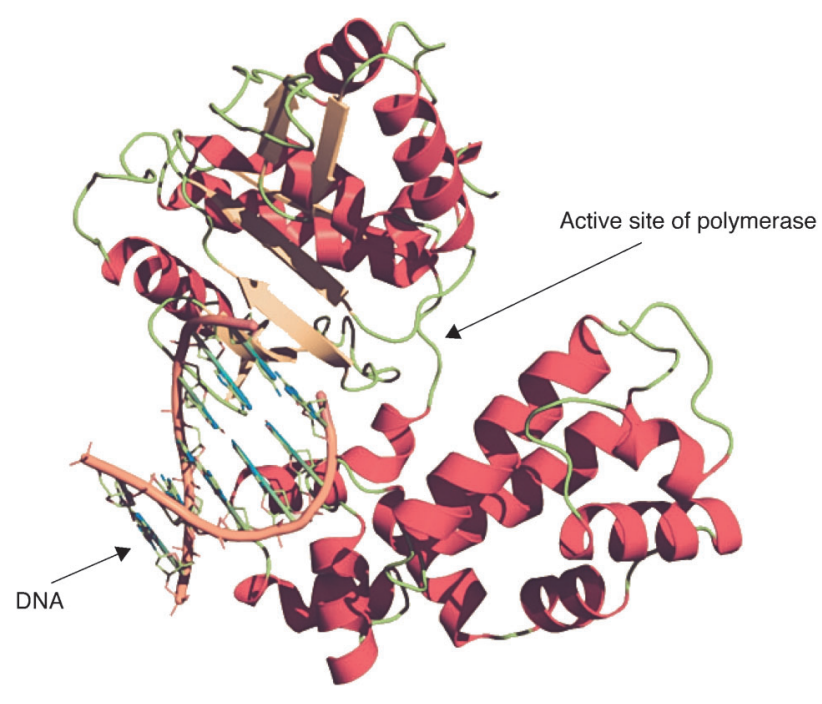

Fig. 5. DNA synthesis occurs at the active site of DNA polymerase. Induced fitting and mutations alter the structure of the active site.

\section{Combination therapy and $\mathrm{HBV}$ resistance}

Recently, the effects of combination therapy were studied and shown to result in reduced drug resistance. Several studies have demonstrated that addition of interferon therapy to NAs, such as lamivudine and adefovir, is beneficial by decreasing viral load. There have been few studies, however, examining the efficacy of combination therapy with regard to the development of drug resistance. One study showed that the rate of resistance in a lamivudine monotherapy group was $25 \%$ compared to $0 \%$ in a combination treatment group. ${ }^{137}$ Another study reported a decrease in HBV replication in patients with lamivudine resistance after adding adefovir to therapy without developing resistance against adefovir over a period of three years. ${ }^{138} \mathrm{~A}$ tenofovir study with lamivudineexperienced and -naive individuals showed that combination therapy with tenofovir and lamivudine was more effective in preventing resistance mutations compared to a group treated with lamivudine alone. ${ }^{139,140}$ Tenofovir was also found to be more effective in viral suppression in combination with emtricitabine in patients with adefovir resistance. ${ }^{141}$ In one study, the rate of adefovir resistant mutations was $15 \%$ in patients treated with combination therapy of lamivudine and adefovir compared to $0 \%$ in patients treated with entecavir and adefovir. Entecavir resistant mutations were found in $4 \%$ patients in the same group. ${ }^{142}$ In contrast, studies have shown an increased rate of HBV resistance in patients sequentially treated with monotherapies. ${ }^{143,144}$ Taken together, the data suggest that while efficacy, in terms of the extent of viral suppression, might not be affected, the rates of resistance appear to be lower with combination therapy. However, more studies are required in larger populations to demonstrate this and whether combination therapy to prevent HBV drug resistance is a cost effective strategy.

\section{Conclusions}

Despite the availability of an effective vaccine for the prevention of HBV infection, thousands of people acquire
HBV infections every year, and many go on to develop chronic hepatitis. Introduction of NAs have significantly impacted HBV treatment. Although these agents are highly potent, there is potential for the selection of viral resistance to NA therapy because of the necessity for long-term treatment, possible exposure to sequential monotherapy, and possible non-compliance. Molecular modeling, in vitro, and clinical studies examining, at the molecular level, the interactions between NAs and other agents with HBV DNA polymerase will assist in the development of new therapeutic agents. These drugs will hopefully lead to complete clearance of HBV from hepatocytes without the risk of developing viral resistance. Overall, the data on drug resistance suggests that the rates of resistance are lower with combination therapy than conventional monotherapy.

\section{Acknowledgements}

We thank the Herman Lopata Chair in Hepatitis Research for supporting our academic activities.

\section{Conflict of interest}

One of the authors (GYW) is a member of medical advisory boards for Gilead, and Bristol-Myers-Squibb.

\section{Author contributions}

Writing the paper (NG, MG), reviewing and editing the paper (CHW, GYW).

\section{References}

[1] Maddrey WC. Hepatitis B: an important public health issue. J Med Virol 2000;61:362-366. doi: 10.1002/1096-9071(200007)61:3<362: :AIDJMV14>3.0.CO;2-I.

[2] Chu CJ, Keeffe EB, Han SH, Perrillo RP, Min AD, Soldevila-Pico C, et al. Hepatitis $B$ virus genotypes in the United States: results of a nationwide study. Gastroenterology 2003;125:444-451. doi: 10.1016/S00165085(03)00895-3.

[3] Blumberg BS, Gerstley B], Hungerford DA, London WT, Sutnick AI. A serum antigen (Australia antigen) in Down's syndrome, leukemia, and hepatitis. Ann Intern Med 1967;66:924-931.

[4] Greenberg HB, Pollard RB, Lutwick LI, Gregory PB, Robinson WS, Merigan TC. Effect of human leukocyte interferon on hepatitis $B$ virus infection in patients with chronic active hepatitis. N Engl J Med 1976;295:517-522.

[5] Fung J, Seto WK, Lai CL, Yuen MF. Nucleoside/nucleotide analogues in the treatment of chronic hepatitis B. J Antimicrob Chemother 2011;66:27152725. doi: 10.1093/jac/dkr388.

[6] Aspinall EJ, Hawkins G, Fraser A, Hutchinson SJ, Goldberg D. Hepatitis B prevention, diagnosis, treatment and care: a review. Occup Med (Lond) 2011;61:531-540. doi: 10.1093/occmed/kqr136.

[7] Liaw YF, Chu CM. Hepatitis B virus infection. Lancet 2009;373:582-592. doi: 10.1016/S0140-6736(09)60207-5.

[8] Zeng W, Yuan J, Liu YX, Zhang Y, Li SX, Yao SM, et al. Efficacy of Peginterferon alpha-2a combinated with entecavir on HBeAg positive chronic hepatitis B patients with high serum hepatitis B viral loads. Zhonghua Shi Yan He Lin Chuang Bing Du Xue Za Zhi 2013;27:115-118.

[9] Crosnier J. Hepatitis B in haemodialysis: vaccination against HBS antigen. Proc Eur Dial Transplant Assoc 1981;18:231-240.

[10] Benhamou E, Courouce AM, Jungers P, Laplanche A, Degos F, Brangier J, et al. Hepatitis $B$ vaccine: randomized trial of immunogenicity in hemodiaIysis patients. Clin Nephrol 1984;21:143-147.

[11] McLean AA. Hepatitis B vaccine: a review of the clinical data to date. J Am Dent Assoc 1985;110:624-628.

[12] Burrell CJ, Gowans EJ, Rowland R, Hall P, Jilbert AR, Marmion BP. Correlation between liver histology and markers of hepatitis $B$ virus replication in infected patients: a study by in situ hybridization. Hepatology 1984;4:2024. doi: 10.1002/hep.1840040104. 
[13] Hadziyannis SJ, Lieberman HM, Karvountzis GG, Shafritz DA. Analysis of liver disease, nuclear HBcAg, viral replication, and hepatitis B virus DNA in liver and serum of HBeAg Vs. anti-HBe positive carriers of hepatitis B virus. Hepatology 1983;3:656-662. doi: 10.1002/hep.1840030505.

[14] Asfandiiarova NS, Fazylova SM, Tkalicheva LI, Dzhavatova LS. Cellular and humoral immunity in asymptomatic carriers of the hepatitis B virus. Ter Arkh 1984;56:47-49.

[15] Hirschman SZ. The hepatitis B virus and its DNA polymerase: the prototype three-D virus. Mol Cell Biochem 1979;26:47-67. doi: 10.1007/ BF00226820.

[16] Summers J, Mason WS. Replication of the genome of a hepatitis B-like virus by reverse transcription of an RNA intermediate. Cell 1982;29:403-415. doi: 10.1016/0092-8674(82)90157-X.

[17] Seeger C, Ganem D, Varmus HE. Biochemical and genetic evidence for the hepatitis B virus replication strategy. Science 1986;232:477-484. doi: $10.1126 /$ science. 3961490

[18] Zoulim F. Therapy of chronic hepatitis B virus infection: inhibition of the vira polymerase and other antiviral strategies. Antiviral Res 1999;44:1-30. doi: 10.1016/S0166-3542(99)00056-X.

[19] Yuen MF, Lai CL. Treatment of chronic hepatitis B: Evolution over two decades. J Gastroenterol Hepatol 2011;26 (Suppl 1):138-143. doi: 10.1111/j.1440-1746.2010.06545.x.

[20] Dropulic LK, Cohen JI. Update on new antivirals under development for the treatment of double-stranded DNA virus infections. Clin Pharmacol Ther 2010;88:610-619. doi: 10.1038/clpt.2010.178.

[21] Miller RH, Kaneko S, Chung CT, Girones R, Purcell RH. Compact organization of the hepatitis B virus genome. Hepatology 1989;9:322-327. doi: 10.1002/hep.1840090226.

[22] Shafritz DA, Lieberman HM. The molecular biology of hepatitis B virus. Annu Rev Med 1984;35:219-232. doi: 10.1146/annurev.me.35.020184. 001251.

[23] Li W, Miao X, Qi Z, Zeng W, Liang J, Liang Z. Hepatitis B virus X protein upregulates HSP90alpha expression via activation of c-Myc in human hepatocarcinoma cell line, HepG2. Virol ] 2010;7:45. doi: 10.1186/1743422X-7-45.

[24] Barbini L, Tadey L, Fernandez S, Bouzas B, Campos R. Molecular characterization of hepatitis $B$ virus $X$ gene in chronic hepatitis $B$ patients. Virol J 2012;9:131. doi: 10.1186/1743-422X-9-131.

[25] Siddiqui A, Jameel $S$, and Mapoles J. Expression of the hepatitis B virus $X$ gene in mammalian cells. Proc Natl Acad Sci U S A 1987;84:2513-2517. doi: $10.1073 /$ pnas.84.8.2513.

[26] Ng SA, Lee C. Hepatitis $B$ virus $X$ gene and hepatocarcinogenesis. J Gastroenterol 2011;46:974-990. doi: 10.1007/s00535-011-0415-9.

[27] Norder H, Couroucé AM, Magnius LO. Molecular basis of hepatitis B virus serotype variations within the four major subtypes. J Gen Virol 1992;73: 3141-3145. doi: 10.1099/0022-1317-73-12-3141.

[28] Okamoto H, Tsuda F, Sakugawa H, Sastrosoewignjo RI, Imai M, Miyakawa Y, et al. Typing hepatitis B virus by homology in nucleotide sequence: comparison of surface antigen subtypes. J Gen Virol 1988;69:25752583. doi: 10.1099/0022-1317-69-10-2575.

[29] Kay A, Zoulim F. Hepatitis B virus genetic variability and evolution. Virus Res, 2007;127:164-176. doi: 10.1016/j.virusres.2007.02.021.

[30] Kramvis A, Kew MC, François G. Hepatitis B virus genotypes. Vaccine 2005; 23:2409-2423. doi: 10.1016/j.vaccine.2004.10.045.

[31] Kramvis A, Kew MC. Relationship of genotypes of hepatitis B virus to mutations, disease progression and response to antiviral therapy. J Viral Hepat 2005;12:456-464. doi: 10.1111/j.1365-2893.2005.00624.x.

[32] Schädler S, Hildt E. HBV life cycle: entry and morphogenesis. Viruses 2009 ; 1:185-209. doi: 10.3390/v1020185.

[33] Mehdi H, Kaplan MJ, Anlar FY, Yang X, Bayer R, Sutherland K, et al. Hepatitis $B$ virus surface antigen binds to apolipoprotein H. J Virol 1994;68:24152424.

[34] Mehdi H, Yang X, Peeples ME. An altered form of apolipoprotein $\mathrm{H}$ binds hepatitis B virus surface antigen most efficiently. Virology 1996;217:5866. doi: 10.1006/viro.1996.0093.

[35] Pontisso P, Ruvoletto MG, Gerlich WH, Heermann KH, Bardini R, Alberti A. Identification of an attachment site for human liver plasma membranes on hepatitis B virus particles. Virology 1989;173:522-530. doi: 10.1016/ 0042-6822(89)90564-3.

[36] Budkowska A, Bedossa P, Groh F, Louise A, Pillot J. Fibronectin of human liver sinusoids binds hepatitis $B$ virus: identification by an anti-idiotypic antibody bearing the internal image of the pre-S2 domain. J Virol 1995;69: 840-848.

[37] Neurath AR, Strick N, Sproul P. Search for hepatitis B virus cell receptors reveals binding sites for interleukin 6 on the virus envelope protein. J Exp Med 1992;175:461-469. doi: 10.1084/jem.175.2.461.

[38] Neurath AR, Strick N, Li YY. Cells transfected with human interleukin 6 cDNA acquire binding sites for the hepatitis $B$ virus envelope protein. J Exp Med 1992;176:1561-1569. doi: 10.1084/jem.176.6.1561.
[39] Breiner KM, Urban S, Schaller H. Carboxypeptidase D (gp180), a Golgiresident protein, functions in the attachment and entry of avian hepatitis $B$ viruses. J Virol 1998;72:8098-8104.

[40] Urban S, Breiner KM, Fehler F, Klingmüller U, Schaller H. Avian hepatitis B virus infection is initiated by the interaction of a distinct pre-S subdomain with the cellular receptor gp180. J Virol 1998;72:8089-8097.

[41] Ryu CJ, Cho DY, Gripon P, Kim HS, Guguen-Guillouzo C, Hong HJ. An 80kilodalton protein that binds to the pre-S1 domain of hepatitis $\mathrm{B}$ virus. J Virol 2000;74:110-116. doi: 10.1128/JVI.74.1.110-116.2000.

[42] Gol'dberg EZ, Ketiladze ES. Molecular biology of hepatitis B virus. Vopr Virusol 1981:525-530.

[43] Lu X, Block TM, Gerlich WH Protease-induced infectivity of hepatitis B virus for a human hepatoblastoma cell line. J Virol 1996;70:2277-2285.

[44] Qiao M, Scougall CA, Duszynski A, Burrell C]. Kinetics of early molecular events in duck hepatitis $B$ virus replication in primary duck hepatocytes. J Gen Virol 1999;80:2127-2135.

[45] Gao W, Hu J. Formation of hepatitis B virus covalently closed circular DNA: removal of genome-linked protein. J Virol 2007;81:6164-6174. doi: 10.1128/JVI.02721-06.

[46] Beck J, Nassal M. Hepatitis B virus replication. World J Gastroenterol 2007; $13: 48-64$.

[47] Nassal M. Hepatitis $B$ viruses: reverse transcription a different way. Virus Res 2008;134:235-249. doi: 10.1016/j.virusres.2007.12.024.

[48] Köck J, Schlicht HJ. Analysis of the earliest steps of hepadnavirus replication: genome repair after infectious entry into hepatocytes does not depend on viral polymerase activity. J Virol 1993;67:4867-4874.

[49] Enders GH, Ganem D, Varmus HE. 5'-terminal sequences influence the segregation of ground squirrel hepatitis virus RNAs into polyribosomes and viral core particles. J Virol 1987; 61:35-41.

[50] Pollack JR, Ganem D. Site-specific RNA binding by a hepatitis B virus reverse transcriptase initiates two distinct reactions: RNA packaging and DNA synthesis. J Virol 1994;68:5579-5587.

[51] Hirsch RC, Lavine JE, Chang LJ, Varmus HE, Ganem D. Polymerase gene products of hepatitis $B$ viruses are required for genomic RNA packaging as wel as for reverse transcription. Nature, $1990 ; 344: 552-555$. doi: 10.1038 / $344552 \mathrm{a} 0$.

[52] Wang GH, Seeger C. Novel mechanism for reverse transcription in hepatitis B viruses. J Virol 1993;67:6507-6512.

[53] Tavis JE, Ganem D. Expression of functional hepatitis B virus polymerase in yeast reveals it to be the sole viral protein required for correct initiation of reverse transcription. Proc Natl Acad Sci U S A 1993;90:4107-4111. doi: 10.1073/pnas.90.9.4107.

[54] Pollack JR, Ganem D. An RNA stem-loop structure directs hepatitis B virus genomic RNA encapsidation. J Virol 1993;67:3254-3263.

[55] Ganem D, Pollack JR, Tavis J. Hepatitis B virus reverse transcriptase and its many roles in hepadnaviral genomic replication. Infect Agents Dis 1994;3: 85-93.

[56] Miller RH, Marion PL, Robinson WS. Hepatitis B viral DNA-RNA hybrid molecules in particles from infected liver are converted to viral DNA molecules during an endogenous DNA polymerase reaction. Virology 1984; 139:64-72. doi: 10.1016/0042-6822(84)90330-1.

[57] Lien JM, Aldrich CE, Mason WS. Evidence that a capped oligoribonucleotide is the primer for duck hepatitis B virus plus-strand DNA synthesis. J Virol $1986 ; 57: 229-236$.

[58] Ma R, Xing Q, Shao L, Wang D, Hao Q, Li X, et al. Hepatitis B virus infection and replication in human bone marrow mesenchymal stem cells. Virol J $2011 ; 8: 486$.

[59] Zoulim F. Assessing hepatitis B virus resistance in vitro and molecular mechanisms of nucleoside resistance. Semin Liver Dis 2002;22 (Suppl 1): 23-31. doi: 10.1055/s-2002-35697.

[60] Lok AS, Zoulim F, Locarnini S, Bartholomeusz A, Ghany MG, Pawlotsky JM, et al. Antiviral drug-resistant HBV: standardization of nomenclature and assays and recommendations for management. Hepatology 2007;46:254265. doi: 10.1002/hep.21698

[61] Lada O, Benhamou Y, Cahour A, Katlama C, Poynard T, Thibault V. In vitro susceptibility of lamivudine-resistant hepatitis B virus to adefovir and tenofovir. Antivir Ther 2004;9:353-363.

[62] Jacquard AC, Brunelle MN, Pichoud C, Durantel D, Carrouée-Durantel S,

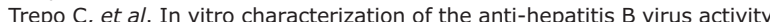
and cross-resistance profile of $2^{\prime}, 3^{\prime}$-dideoxy-3'-fluoroguanosine. Antimicrob Agents Chemother 2006;50:955-961. doi: 10.1128/ AAC.50.3.955-961.2006.

[63] European Association For The Study Of The Liver. Management of chronic hepatitis B virus infection. Journal of Hepatology 2012;57: $167-185$.

[64] Rockstroh JK, Bhagani S, Benhamou Y, Bruno R, Mauss S, Peters L, et al. European AIDS Clinical Society (EACS) guidelines for the clinical management and treatment of chronic hepatitis $B$ and $C$ coinfection in HIV-infected adults. HIV Med 2008;9:82-88. doi: 10.1111/j.1468-1293.2007.00535.x. 
[65] Yang JX, Liu BM, Li XG, Yan CH, Xu J, Sun XW, et al. Profile of HBV antiviral resistance mutations with distinct evolutionary pathways against nucleoside/nucleotide analogue treatment among Chinese chronic hepatitis $B$ patients. Antivir Ther 2010;15:1171-1178. doi: 10.3851/IMP1677.

[66] Perrillo R. Benefits and risks of interferon therapy for hepatitis B. Hepatology 2009;49(5 Suppl):S103-111. doi: 10.1002/hep.22956.

[67] Horsmans Y, Colle I, Van Vlierberghe H, Langlet P, Adler M, Bourgeois N, et $a$. Weekly pegylated interferon alpha- $2 b$ vs daily interferon $a-2 b$ versus standard regimen of interferon $a-2 b$ in the treatment of patients with chronic hepatitis C virus infection. Acta Gastroenterol Belg 2008;71:293297.

[68] Bhattacharya D, Thio CL. Review of hepatitis B therapeutics. Clin Infect Dis 2010;51:1201-1208. doi: 10.1086/656624.

[69] Cooksley WG, Piratvisuth T, Lee SD, Mahachai V, Chao YC, Tanwandee T, et al. Peginterferon alpha-2a (40 kDa): an advance in the treatment of hepatitis B e antigen-positive chronic hepatitis B. J Viral Hepat 2003;10: 298-305. doi: 10.1046/j.1365-2893.2003.00450.x.

[70] Sen, G.C., Viruses and interferons. Annu Rev Microbiol 2001;55:255-281. doi: 10.1146/annurev.micro.55.1.255.

[71] Darnell JE Jr, Kerr IM, Stark GR. Jak-STAT pathways and transcriptional activation in response to IFNs and other extracellular signaling proteins. Science 1994;264:1415-1421. doi: 10.1126/science.8197455.

[72] Rang A, Bruns M, Heise T, Will H. Antiviral activity of interferon-alpha against hepatitis $B$ virus can be studied in non-hepatic cells and Is independent of MxA. J Biol Chem 2002;277:7645-7647. doi: 10.1074/ jbc.C100729200.

[73] Guidotti LG, Morris A, Mendez H, Koch R, Silverman RH, Williams BR, et al. Interferon-regulated pathways that control hepatitis $\mathrm{B}$ virus replication in transgenic mice. J Virol 2002;76:2617-2621. doi: 10.1128/JVI.76.6.26172621.2002.

[74] Chan HL. Peginterferon therapy for chronic hepatitis B: one size fits all? Gut 2013;62:185-187. doi: 10.1136/gutjnl-2012-303291.

[75] Seehofer D, Rayes N, Berg T, Neuhaus R, Hopf U, Müller AR, et al. Additional interferon alpha for lamivudine resistant hepatitis B infection after liver transplantation: a preliminary report. Transplantation 2000;69:17394172. doi: 10.1097/00007890-200004270-00039.

[76] Liaw YF. Natural history of chronic hepatitis B virus infection and long-term outcome under treatment. Liver Int 2009;29 (Suppl 1):100-107. doi: 10.1111/j.1478-3231.2008.01941.x.

[77] Newbold JE, Xin H, Tencza M, Sherman G, Dean J, Bowden S, et al. The covalently closed duplex form of the hepadnavirus genome exists in situ as a heterogeneous population of viral minichromosomes. J Virol 1995;69: 3350-3357.

[78] Wong DK, Yuen MF, Yuan H, Sum SS, Hui CK, Hall J, et al. Quantitation of covalently closed circular hepatitis B virus DNA in chronic hepatitis B patients. Hepatology 2004;40:727-737. doi: 10.1002/hep.20353.

[79] Lai CL, Chien RN, Leung NW, Chang TT, Guan R, Tai DI, et al. A one-year trial of lamivudine for chronic hepatitis B. Asia Hepatitis Lamivudine Study Group. N Engl J Med 1998;339:61-68. doi: 10.1056/NEJM199807093390201.

[80] Dienstag JL, Schiff ER, Wright TL, Perrillo RP, Hann HW, Goodman Z, et al. Lamivudine as initial treatment for chronic hepatitis B in the United States. N Engl J Med 1999;341:1256-1263. doi: 10.1056/NEJM199910213411702.

[81] Liaw YF, Sung J], Chow WC, Farrell G, Lee CZ, Yuen H, et al. Lamivudine for patients with chronic hepatitis B and advanced liver disease. N Engl J Med 2004;351:1521-1531. doi: 10.1056-NEJMoa033364.

[82] Yuen MF, Seto WK, Chow DH, Tsui K, Wong DK, Ngai VW, et al. Long-term lamivudine therapy reduces the risk of long-term complications of chronic hepatitis B infection even in patients without advanced disease. Antivir Ther 2007; $12: 1295-1303$.

[83] Leung NW, Lai CL, Chang TT, Guan R, Lee CM, Ng KY, et al. Extended lamivudine treatment in patients with chronic hepatitis $\mathrm{B}$ enhances hepatitis $\mathrm{B}$ e antigen seroconversion rates: results after 3 years of therapy. Hepatology 2001;33:1527-1532. doi: 10.1053/jhep.2001.25084.

[84] Lai CL, Dienstag J, Schiff E, Leung NW, Atkins M, Hunt C, et al. Prevalence and clinical correlates of YMDD variants during lamivudine therapy for patients with chronic hepatitis B. Clin Infect Dis 2003;36:687-696. doi: $10.1086 / 368083$

[85] Bottecchia M, Ikuta N, Niel C, Araujo NM, O KM, Gomes SA. Lamivudine resistance and other mutations in the polymerase and surface antigen genes of hepatitis B virus associated with a fatal hepatic failure case. J Gastroenterol Hepatol 2008;23:67-72. doi: 10.1111/j.1440-1746.2007. 05238.x.

[86] Pallier C, Castéra L, Soulier A, Hézode C, Nordmann $P$, Dhumeaux D, et al. Dynamics of hepatitis B virus resistance to lamivudine. J Virol 2006;80: 643-653. doi: 10.1128/JVI.80.2.643-653.2006.

[87] Wilchek M, Bayer EA, Livnah O. Essentials of biorecognition: the (strept)avidin-biotin system as a model for protein-protein and protein-ligand interaction. Immunol Lett 2006;103:27-32. doi: 10.1016/j.imlet.2005.10.022.

[88] Williams DH, Stephens E, O'Brien DP, Zhou M. Understanding noncovalent interactions: ligand binding energy and catalytic efficiency from ligand-induced reductions in motion within receptors and enzymes. Angew Chem Int Ed Engl 2004;43:6596-6616. doi: 10.1002/anie.200300644.

[89] Sharon A, Chu CK. Understanding the molecular basis of HBV drug resistance by molecular modeling. Antiviral Res 2008;80:339-353. doi: 10.1016/j.antiviral.2008.07.010.

[90] Tanji N, Tanji K, Kambham N, Markowitz GS, Bell A, D’agati VD. Adefovir nephrotoxicity: possible role of mitochondrial DNA depletion. Hum Pathol 2001;32:734-740. doi: 10.1053/hupa.2001.25586.

[91] Ha NB, Ha NB, Garcia RT, Trinh HN, Vu AA, Nguyen HA, et al. Renal dysfunction in chronic hepatitis $B$ patients treated with adefovir dipivoxil. Hepatology 2009;50:727-734. doi: 10.1002/hep.23044.

[92] Hannon $\mathrm{H}$, Bagnis CI, Benhamou Y, Beaufils H, Sullivan M, Brosgart C, et al. The renal tolerance of low-dose adefovir dipivoxil by lamivudine-resistant individuals co-infected with hepatitis B and HIV. Nephrol Dial Transplant 2004;19:386-390. doi: 10.1093/ndt/gfg505.

[93] Angus $\mathrm{P}$, Vaughan $\mathrm{R}$, Xiong $\mathrm{S}$, Yang $\mathrm{H}$, Delaney W, Gibbs C, et al. Resistance to adefovir dipivoxil therapy associated with the selection of a novel mutation in the HBV polymerase. Gastroenterology 2003;125:292-297. doi: 10.1016/S0016-5085(03)00939-9.

[94] Monavari SH, Keyvani $\mathrm{H}$, Mollaie $\mathrm{H}$, Roudsari RV. Detection of rtN236T mutation associated with adefovir dipivoxil resistance in Hepatitis $\mathrm{B}$ infected patients with YMDD mutations in Tehran. Iran J Microbiol 2013;5: $76-80$.

[95] Schildgen O, Olotu C, Funk A, Zöllner B, Helm M, Rockstroh JK, et al. Selection and counterselection of the rtI233V adefovir resistance mutation during antiviral therapy. J Clin Microbiol 2010;48:631-634. doi: 10.1128/ JCM.01073-09.

[96] R Ryu SH, Chung YH. Resistance to adefovir in patients with chronic hepatitis B. Korean J Hepatol 2006;12:484-492.

[97] Lampertico P, Viganò M, Manenti E, Iavarone M, Lunghi G, Colombo M. Adefovir rapidly suppresses hepatitis $B$ in $\mathrm{HBeAg}$-negative patients developing genotypic resistance to lamivudine. Hepatology 2005;42:14141419. doi: 10.1002/hep.20939.

[98] Cortelezzi A, Viganò M, Zilioli VR, Fantini NN, Pasquini MC, Deliliers GL, et al. Adefovir added to lamivudine for hepatitis $B$ recurrent infection in refractory B-cell chronic lymphocytic leukemia on prolonged therapy with Campath1H. J Clin Virol 2006;35:467-469. doi: 10.1016/j.jcv.2005.10.009.

[99] Seifer M, Hamatake RK, Colonno RJ, Standring DN. In vitro inhibition of hepadnavirus polymerases by the triphosphates of BMS-200475 and lobucavir. Antimicrob Agents Chemother 1998;42:3200-3208.

[100] Langley DR, Walsh AW, Baldick C], Eggers B], Rose RE, Levine SM, et al. Inhibition of hepatitis B virus polymerase by entecavir. J Virol 2007;81: 3992-4001. doi: 10.1128/JVI.02395-06.

[101] Billich A. Entecavir (Bristol-Myers Squibb). Curr Opin Investig Drugs 2001 2:617-621.

[102] Tchesnokov EP, Obikhod A, Schinazi RF, Götte M. Delayed chain termination protects the anti-hepatitis $B$ virus drug entecavir from excision by HIV-1 reverse transcriptase. J Biol Chem 2008;283:34218-34228. doi: 10.1074/ jbc.M806797200.

[103] Tenney DJ, Rose RE, Baldick C], Pokornowski KA, Eggers BJ, Fang J, et al. Long-term monitoring shows hepatitis $B$ virus resistance to entecavir in nucleoside-naive patients is rare through 5 years of therapy. Hepatology 2009;49:1503-1514. doi: 10.1002/hep.22841.

[104] Chang TT, Lai CL, Kew Yoon S, Lee SS, Coelho HS, Carrilho FJ, et al. Entecavir treatment for up to 5 years in patients with hepatitis $B$ e antigenpositive chronic hepatitis B. Hepatology 2010;51:422-430. doi: 10.1002/ hep. 23327.

[105] Chang TT, Liaw YF, Wu SS, Schiff E, Han $\mathrm{KH}$, Lai $\mathrm{CL}$, et al. Long-term entecavir therapy results in the reversal of fibrosis/cirrhosis and continued histological improvement in patients with chronic hepatitis B. Hepatology 2010;52:886-893. doi: 10.1002/hep.23785.

[106] Lai CL, Rosmawati M, Lao J, Van Vlierberghe $\mathrm{H}$, Anderson FH, Thomas $\mathrm{N}$, et al. Entecavir is superior to lamivudine in reducing hepatitis $B$ virus DNA in patients with chronic hepatitis B infection. Gastroenterology 2002;123 1831-1838. doi: 10.1053/gast.2002.37058.

[107] Innaimo SF, Seifer M, Bisacchi GS, Standring DN, Zahler R, Colonno RJ. Identification of BMS-200475 as a potent and selective inhibitor of hepatitis B virus. Antimicrob Agents Chemother 1997;41:1444-1448.

[108] Chang TT, Gish RG, de Man R, Gadano A, Sollano J, Chao YC, et al. A comparison of entecavir and lamivudine for $\mathrm{HBeAg-positive} \mathrm{chronic}$ hepatitis B. N Engl J Med 2006;354:1001-1010. doi: 10.1056/ NEJMoa051285.

[109] Lai CL, Shouval D, Lok AS, Chang $\Pi$, Cheinquer $H$, Goodman $Z$, et al. Entecavir versus lamivudine for patients with $\mathrm{HBeAg}$-negative chronic hepatitis B. N Engl J Med 2006;354:1011-1020. doi: 10.1056/ NEJMoa051287.

[110] Dienstag JL, Wei LJ, Xu D, Kreter B. Cross-study analysis of the relative efficacies of oral antiviral therapies for chronic hepatitis $B$ infection in nucleoside-naive patients. Clin Drug Investig 2007;27:35-49. doi: $10.2165 / 00044011-200727010-00003$ 
[111] Tenney DJ, Levine SM, Rose RE, Walsh AW, Weinheimer SP, Discotto L, et al. Clinical emergence of entecavir-resistant hepatitis $B$ virus requires additional substitutions in virus already resistant to Lamivudine. Antimicrob Agents Chemother 2004;48:3498-507. doi: 10.1128/AAC.48.9.34983507.2004.

[112] Villet S, Ollivet A, Pichoud C, Barraud L, Villeneuve JP, Trépo C, et al. Stepwise process for the development of entecavir resistance in a chronic hepatitis B virus infected patient. J Hepatol 2007;46:531-538. doi: 10.1016/j.jhep.2006.11.016.

[113] Baldick CJ, Tenney DJ, Mazzucco CE, Eggers BJ, Rose RE, Pokornowski KA, et al. Comprehensive evaluation of hepatitis B virus reverse transcriptase substitutions associated with entecavir resistance. Hepatology 2008;47: 1473-1482. doi: 10.1002/hep.22211.

[114] Han SH. Telbivudine: a new nucleoside analogue for the treatment of chronic hepatitis B. Expert Opin Investig Drugs 2005;14:511-519. doi: 10.1517/13543784.14.4.511.

[115] Lai CL, Gane E, Liaw YF, Hsu CW, Thongsawat S, Wang Y, et al. Telbivudine versus lamivudine in patients with chronic hepatitis B. N Engl J Med 2007; 357:2576-2588. doi: 10.1056/NEJMoa066422.

[116] Lai CL, Leung N, Teo EK, Tong M, Wong F, Hann HW, et al. A 1-year trial of telbivudine, lamivudine, and the combination in patients with hepatitis $\mathrm{B}$ e antigen-positive chronic hepatitis B. Gastroenterology 2005;129:528-536. doi: $10.1016 /$ j.gastro.2005.05.053.

[117] Zhao S, Tang L, Fan X, Chen $L$, Zhou R, Dai X. Comparison of the efficacy of lamivudine and telbivudine in the treatment of chronic hepatitis $\mathrm{B}$ : a systematic review. Virol J 2010;7:211. doi: 10.1186/1743-422X-7-211.

[118] Safadi R, Xie Q, Chen Y, Yin YK, Wei L, Hwang SG, et al. Efficacy of switching to telbivudine in chronic hepatitis B patients treated previously with lamivudine. Liver Int 2011;31:667-675. doi: 10.1111/j.1478-3231.2010.02360.x.

[119] Osborn MK. Safety and efficacy of telbivudine for the treatment of chronic hepatitis B. Ther Clin Risk Manag 2009;5:789-798.

[120] Seto WK, Lai CL, Fung J, Wong DK, Yuen JC, Hung IF, et al. Significance of HBV DNA levels at 12 weeks of telbivudine treatment and the 3 years treatment outcome. J Hepatol 2011;55:522-528. doi: 10.1016/ j.jhep.2010.11.018.

[121] Lei J, Wang Y, Wang LL, Zhang SJ, Chen W, Bai ZG, et al. Profile of hepatitis $B$ virus resistance mutations against nucleoside/nucleotide analogue treatment in Chinese patients with chronic hepatitis B. Virol J 2013;10: 313. doi: $10.1186 / 1743-422 X-10-313$.

[122] Wang M, Da Y, Cai H, Lu Y, Wu L, Jia J. Telbivudine myopathy in a patient with chronic hepatitis B. Int J Clin Pharm 2012;34:422-425. doi: 10.1007/ s11096-012-9633-3.

[123] Zhang XS, Jin R, Zhang SB, Tao ML. Clinical features of adverse reactions associated with telbivudine. World J Gastroenterol 2008;14:3549-3553.

[124] Ren JB, Wang Y, Li HY, Sun SJ, Jia JD, Ma H. Telbivudine-associated creatine kinase elevation in chronic hepatitis B patients. Zhonghua Gan Zang Bing Za Zhi 2012;20:641-643. doi: 10.3760/cma.j.issn.1007-3418.2012. 09.001.

[125] Marcellin P, Heathcote EJ, Buti M, Gane E, de Man RA, Krastev Z, et al. Tenofovir disoproxil fumarate versus adefovir dipivoxil for chronic hepatitis B. N Engl J Med 2008;359:2442-2455. doi: 10.1056/NEJMoa0802878.

[126] Heathcote EJ, Marcellin P, Buti M, Gane E, De Man RA, Krastev Z, et al. Three-year efficacy and safety of tenofovir disoproxil fumarate treatment for chronic hepatitis B. Gastroenterology 2011;140:132-143. doi: $10.1053 /$ j.gastro.2010.10.011.

[127] Izzedine H, Hulot JS, Vittecoq D, Gallant JE, Staszewski S, Launay-Vacher V et al. Long-term renal safety of tenofovir disoproxil fumarate in antiretroviral-naive HIV-1-infected patients. Data from a double-blind randomized active-controlled multicentre study. Nephrol Dial Transplant 2005. 20:743-746. doi: 10.1093/ndt/gfh658.

[128] Kitrinos KM, Corsa A, Liu Y, Flaherty J, Snow-Lampart A, Marcellin P, et al. No detectable resistance to tenofovir disoproxil fumarate after 6 years of therapy in patients with chronic hepatitis B. Hepatology 2014;59:434-442. doi: $10.1002 / h e p .26686$

[129] Liu Y, Miller MD, Kitrinos KM. HBV clinical isolates expressing adefovir resistance mutations show similar tenofovir susceptibilities across genotypes B, C and D. Liver Int 2014;34:1025-1032. doi: 10.1111/liv.12343

[130] Qi X, Xiong S, Yang H, Miller M, Delaney WE 4th. In vitro susceptibility of adefovir-associated hepatitis $\mathrm{B}$ virus polymerase mutations to other antiviral agents. Antivir Ther 2007;12:355-362.

[131] Villet S, Pichoud C, Billioud G, Barraud L, Durantel S, Trépo C, et al. Impact of hepatitis B virus rtA181V/T mutants on hepatitis B treatment failure. J Hepatol 2008;48:747-755. doi: 10.1016/j.jhep.2008.01.027.

[132] Coca S, Perazella MA. Rapid communication: acute renal failure associated with tenofovir: evidence of drug-induced nephrotoxicity. Am J Med Sci 2002;324:342-344.

[133] Moreno S, Domingo P, Palacios R, Santos J, Falcó V, Murillas J, et al. Rena safety of tenofovir disoproxil fumarate in HIV-1 treatment-experienced patients with adverse events related to prior NRTI use: data from a prospective, observational, multicenter study. J Acquir Immune Defic Syndr 2006;42:385-387. doi: 10.1097/01.qai.0000221690.54349.83.

[134] Zimmermann AE, Pizzoferrato T, Bedford J, Morris A, Hoffman R, Braden G. Tenofovir-associated acute and chronic kidney disease: a case of multiple drug interactions. Clin Infect Dis 2006;42:283-290. doi: 10.1086/499048.

[135] Grund B, Peng G, Gibert CL, Hoy JF, Isaksson RL, Shlay JC, et al. Continuous antiretroviral therapy decreases bone mineral density. AIDS 2009;23: 1519-1529. doi: 10.1097/QAD.0b013e32832c1792.

[136] Parsonage MJ, Wilkins EG, Snowden N, Issa BG, Savage MW. The development of hypophosphataemic osteomalacia with myopathy in two patients with HIV infection receiving tenofovir therapy. HIV Med 2005;6: 341-346. doi: 10.1111/j.1468-1293.2005.00318.x.

[137] Vassiliadis T, Tziomalos K, Patsiaoura K, Zagris T, Giouleme O, Soufleris K, et al. Lamivudine/pegylated interferon alfa-2b sequential combination therapy compared with lamivudine monotherapy in HBeAg-negative chronic hepatitis B. J Gastroenterol Hepatol 2007;22:1582-1588. doi: 10.1111/j.1440-1746.2007.05103.x.

[138] Rapti I, Dimou E, Mitsoula P, Hadziyannis SJ. Adding-on versus switching-to adefovir therapy in lamivudine-resistant $\mathrm{HBeAg}$-negative chronic hepatitis B. Hepatology 2007;45:307-313. doi: 10.1002/hep.21534.

[139] Dore G], Cooper DA, Pozniak AL, DeJesus E, Zhong L, Miller MD, et al. Efficacy of tenofovir disoproxil fumarate in antiretroviral therapy-naive and -experienced patients coinfected with HIV-1 and hepatitis B virus. J Infect Dis 2004;189:1185-1192. doi: 10.1086/380398.

[140] Sheldon J, Camino N, Rodés B, Bartholomeusz A, Kuiper M, Tacke F, et al. Selection of hepatitis B virus polymerase mutations in HIV-coinfected patients treated with tenofovir. Antivir Ther 2005;10:727-734.

[141] Tan J, Degertekin B, Wong SN, Husain M, Oberhelman K, Lok AS. Tenofovir monotherapy is effective in hepatitis $B$ patients with antiviral treatment failure to adefovir in the absence of adefovir-resistant mutations. J Hepatol 2008;48:391-398. doi: 10.1016/j.jhep.2007.09.020.

[142] Lim YS, Lee JY, Lee D, Shim JH, Lee HC, Lee YS, et al. Randomized trial of entecavir plus adefovir in patients with lamivudine-resistant chronic hepatitis B who show suboptimal response to lamivudine plus adefovir. Antimicrob Agents Chemother 2012;56:2941-2947. doi: 10.1128/ AAC.00338-12.

[143] Villet S, Pichoud C, Villeneuve JP, Trépo C, Zoulim F. Selection of a multiple drug-resistant hepatitis B virus strain in a liver-transplanted patient. Gastroenterology 2006;131:1253-1261. doi: 10.1053/j.gastro.2006.08.013.

[144] Brunelle MN, Jacquard AC, Pichoud C, Durantel D, Carrouée-Durantel S, Villeneuve JP, et al. Susceptibility to antivirals of a human HBV strain with mutations conferring resistance to both lamivudine and adefovir. Hepatology 2005;41:1391-1398. doi: 10.1002/hep.20723.

[145] Stuyver L, De Gendt S, Van Geyt C, Zoulim F, Fried M, Schinazi RF, et al. A new genotype of hepatitis $B$ virus: complete genome and phylogenetic relatedness. J Gen Virol 2000;81:67-74.

[146] Norder H, Couroucé AM, Magnius LO. Complete genomes, phylogenetic relatedness, and structural proteins of six strains of the hepatitis B virus, four of which represent two new genotypes. Virology 1994;198:489-503. doi: 10.1006/viro.1994.1060.

[147] Norder H, Hammas B, Lee SD, Bile K, Couroucé AM, Mushahwar IK, et al. Genetic relatedness of hepatitis B viral strains of diverse geographical origin and natural variations in the primary structure of the surface antigen. J Gen Virol 1993;74:1341-1348. doi: 10.1099/0022-1317-74-7-1341.

[148] Lindh M, Andersson AS, Gusdal A. Genotypes, nt 1858 variants, and geographic origin of hepatitis B virus-large-scale analysis using a new genotyping method. J Infect Dis 1997;175:1285-1293. doi: 10.1086/ 516458.

[149] Westland C, Delaney W 4th, Yang H, Chen SS, Marcellin P, Hadziyannis S, et al. Hepatitis B virus genotypes and virologic response in 694 patients in phase III studies of adefovir dipivoxil1. Gastroenterology 2003;125:107116. doi: 10.1016/S0016-5085(03)00700-5.

[150] Odemuyiwa SO, Mulders MN, Oyedele OI, Ola SO, Odaibo GN, Olaleye DO, et al. Phylogenetic analysis of new hepatitis B virus isolates from Nigeria supports endemicity of genotype E in West Africa. J Med Virol 2001;65: 463-469. doi: 10.1002/jmv.2058.

[151] Arauz-Ruiz P, Norder H, Visoná KA, Magnius LO. Genotype F prevails in HBV infected patients of hispanic origin in Central America and may carry the precore stop mutant. J Med Virol 1997;51:305-312. doi: 10.1002/ (SICI)1096-9071(199704)51:4<305::AID-JMV8>3.0.CO;2-9.

[152] Sanchez LV, Maldonado M, Bastidas-Ramírez BE, Norder H, Panduro A. Genotypes and S-gene variability of Mexican hepatitis B virus strains. J Med Virol 2002;68:24-32. doi: 10.1002/jmv.10166.

[153] Vieth S, Manegold C, Drosten C, Nippraschk T, Günther S. Sequence and phylogenetic analysis of hepatitis B virus genotype $\mathrm{G}$ isolated in Germany Virus Genes 2002;24:153-156. doi: 10.1023/A:1014572600432. 